\title{
Zmiany w układzie krążenia u pacjentów z toczniem rumieniowatym układowym
}

\section{Circulatory system in patients with systemic lupus erythematosus}

\author{
Anna Chrzanowska, Katarzyna Irzyk, Iwona Dudzik-Niewiadomska, Piotr Bienias, Michał Ciurzyński \\ Klinika Chorób Wewnętrznych i Kardiologii z Centrum Leczenia Żylnej Choroby Zakrzepowo-Zatorowej \\ Warszawskiego Uniwersytetu Medycznego
}

\section{Streszczenie}

Toczeń rumieniowaty układowy (SLE) jest chorobą zapalną tkanki łącznej o podłożu autoimmunologicznym, o różnorodnej manifestacji klinicznej i serologicznej. W wyniku złożonych zaburzeń układu odpornościowego i przewlekłego procesu zapalnego dochodzi do uszkodzenia wielu narządów i tkanek. Do najczęstszych powikłań sercowo-naczyniowych należą: przedwczesna choroba wieńcowa, zapalenie osierdzia, zapalenie mięśnia sercowego, uszkodzenie zastawek serca, zaburzenia rytmu serca, nadciśnienie płucne $(\mathrm{PH})$, powikłania zakrzepowo-zatorowe, nadciśnienie tętnicze $(\mathrm{AH})$ i niewydolność serca oraz patognomoniczne dla SLE nieinfekcyjne zapalenie wsierdzia typu Libmana i Sacksa. Szczególne znaczenie w rokowaniu u pacjentów z SLE ma przedwczesna progresja miażdżycy prowadząca między innymi do rozwoju choroby wieńcowej, zwłaszcza u młodych kobiet. Zwiększone ryzyko nagłych zdarzeń sercowo-naczyniowych u pacjentów z SLE potwierdzono w wielu badaniach naukowych. Pogłębienie wiedzy na temat zmian zachodzących w układzie sercowo-naczyniowym, a zwłaszcza patofizjologii przyśpieszonej aterogenezy w przebiegu SLE, może w przyszłości przyczynić się do istotnej poprawy przeżywalności chorych. Niniejszy artykuł ma na celu omówienie etiologii oraz przebiegu powikłań kardiologicznych u pacjentów z SLE.

Słowa kluczowe: toczeń rumieniowaty układowy, powikłania kardiologiczne, miażdżyca, choroba wieńcowa

Folia Cardiologica 2016; 11, 2: 111-118

\section{Wstęp}

Toczeń rumieniowaty układowy (SLE, systemic lupus erythematosus) jest przewlekłą chorobą zapalną tkanki łącznej o podłożu autoimmunologicznym, w której złożone zaburzenia układu odpornościowego prowadzą do zapalenia i uszkodzenia wielu narządów. Najczęściej w przebiegu choroby obserwuje się zajęcie skóry, nerek, płuc, serca, układu ruchu oraz układu nerwowego. Częstość występowania SLE w populacji kaukaskiej wynosi 20-50/100 000. Zapadalność szacuje się na 3-5/100 000 osób rocznie, najczęściej między 16. a 55. rokiem życia [1]. W ostatnich latach postęp w diagnostyce oraz nowe możliwości leczenia miały wpływ na istotną poprawę przeżywalności pacjentów z SLE. Obecnie przeżywalność 5-letnia wynosi około 93\%, a 10-letnia - 85\%. Jednak umieralność chorych na SLE jest wciąż 3-5-krotnie większa niż w populacji ogólnej [2]. W 1827 roku Moritz Kaposi (węgierski lekarz dermatolog) zidentyfikował i opisał zmiany narządowe w przebiegu SLE. Jednak dopiero w roku 1940 Louis Gross (amerykański lekarz patofizjolog) powiązał występowanie nietypowego nieinfekcyjnego zapalenia wsierdzia (opisanego przez Libmana i Sacksa w 1924 r.) z rozpoznaniem SLE. Obecnie wiadomo, że zmiany w układzie krążenia dotyczą najczęściej osierdzia 
Tabela 1. Powikłania sercowo-naczyniowe u pacjentów z toczniem rumieniowatym układowym (SLE, systemic lupus erythematosus)

\begin{tabular}{lc}
\hline Choroba & $\begin{array}{c}\text { Częstość } \\
\text { występowania (\%) }\end{array}$ \\
\hline Miażdżyca & $>50$ \\
Zapalenie osierdzia & $>50$ \\
Zapalenie mięśnia sercowego & $8-25$ \\
Pogrubienie płatków zastawek & $51-52$ \\
Wegetacje na zastawkach serca & $6-43$ \\
Nieinfekcyjne zapalenie wsierdzia & \\
typu Libmana i Sacksa & \\
Niedomykalność mitralna, aortalna & Ok. 28 \\
Stenoza mitralna, aortalna & $3-4$ \\
Zaburzenia rytmu serca i przewodzenia & $34-70$ \\
Nadciśnienie tętnicze & Ok. 70 \\
Zatorowość płucna u pacjentów z wtórnym & $14-20$ \\
do SLE zespołem antyfosfolipidowym & \\
Nadciśnienie płucne & $4-14$
\end{tabular}

(wysiękowe zapalenie osierdzia) oraz zastawek (dysfunkcja zastawek i nieinfekcyjne zapalenie wsierdzia typu Libmana i Sacksa). Ponadto u pacjentów z SLE występuje zwiększone ryzyko miażdżycy naczyń wieńcowych. W odróżnieniu od populacji ogólnej najważniejszą rolę w patogenezie aterogenezy odgrywają przewlekły stan zapalny oraz obecność licznych przeciwciał. Powikłania w układzie krążenia stanowią tylko jedną z wielu możliwych manifestacji SLE, jednak zdarzenia sercowo-naczyniowe są główną przyczyną zgonów, zwłaszcza w późnej fazie choroby. W niniejszej pracy przedstawiono możliwe powikłania kardiologiczne u chorych na SLE.

\section{Najczęstsze powikłania w układzie sercowo-naczyniowym w przebiegu tocznia rumieniowatego układowego}

Najczęstsze powikłania w układzie krążenia u pacjentów z SLE przedstawiono w tabeli 1.

\section{Miażdżyca}

Pacjenci z SLE cechują się zwiększonym ryzykiem wystąpienia miażdżycy naczyń wieńcowych, która pojawia się u nich w młodszym wieku niż w populacji ogólnej [3]. Zdarzenia sercowo-naczyniowe stanowią główną przyczynę zgonów w tej grupie chorych. Bernatsky i wsp. przeprowadzili wieloośrodkowe międzynarodowe badanie kohortowe celem oceny umieralności pacjentów z SLE. Porównano liczbę zgonów chorych z SLE z oczekiwaną liczbą zgonów w populacji ogólnej. Do badania włączono 9547 osób z SLE, które obserwowano przez średnio 8,1 roku (90\% badanej grupy stanowiły kobiety). W trakcie obserwacji 1255 osób zmarło. Najczęstszą przyczyną zgonów były zdarzenia sercowo-naczyniowe (313 osób), rozumiane jako wszelkie choroby serca, tętnic oraz udary mózgu. Standaryzowany współczynnik śmiertelności (SMR, standard mortality ratio) - stosunek rzeczywistych zgonów do przewidywanej liczby zgonów dla zdarzeń sercowo-naczyniowych wynosił 1,7 (95-proc. przedział ufności [Cl, confidence interval] 1,5-1,9) [4]. W niedawno opublikowanej pracy Ballocca i wsp. ocenili częstość występowania zdarzeń sercowo-naczyniowych u 17187 pacjentów z SLE poddanych średnio 8-letniej obserwacji. Zdarzenia sercowo-naczyniowe stwierdzono u 25,4\% pacjentów z SLE (u 4,1\% chorych wystąpił zawał serca, a u 7,3\% - udar mózgu) [5]. W badaniach autopsyjnych młodych pacjentów z SLE miażdżyce stwierdzono u ponad 50\% badanych [6, 7]. Niepokojące są doniesienia o chorobie wieńcowej u młodych kobiet z SLE (w 3. i 4. dekadzie życia), które potencjalnie powinny znajdować się w grupie najmniejszego ryzyka rozwoju miażdżycy [3]. Manzi i wsp. poddali analizie 498 pacjentek z SLE oraz grupe 2208 zdrowych kobiet uczestniczących w badaniu Framingham Offspring Study. Badacze wykazali, że u pacjentek z SLE między 35. a 44. rokiem życia 50-krotnie częściej występował zawał serca [8]. Za przyspieszony rozwój miażdżycy u chorych z SLE w części odpowiadają takie klasyczne czynniki ryzyka choroby wieńcowej, jak: otyłość, siedzący tryb życia, nadciśnienie tętnicze (AH, arterial hypertension), zaburzenia gospodarki węglowodanowej i lipidowej. Jednak, jak pokazują liczne analizy, zdarzenia sercowo-naczyniowe u pacjentów z SLE nie wynikają jedynie z tradycyjnych czynników ryzyka. Choroba sama w sobie oraz leczenie za pomocą glikokortykosteroidów (GKS) stanowią istotny element w rozwoju miażdżycy. Rahman i wsp. opublikowali wyniki retrospektywnego badania służącego porównaniu częstości występowania klasycznych czynników ryzyka miażdżycy u pacjentów z SLE i chorobą wieńcową (35osób; 27 kobiet i 8 mężczyzn) z dobraną wiekowo grupą osób z chorobą wieńcową. Badacze wykazali, że pacjenci z SLE, u których wystąpił epizod wieńcowy prezentowali mniej tradycyjnych czynników ryzyka niż badani z grupy kontrolnej. Dla kobiet liczba klasycznych czynników ryzyka choroby wieńcowej w przeliczeniu na liczbę zdarzeń sercowo-naczyniowych wynosiła odpowiednio w grupie z SLE 2,0 $\pm 0,77$, w grupie kontrolnej 2,90 $\pm 1,19(p=0,0008)$; dla mężczyzn z SLE $1,87 \pm 0,83$, w grupie kontrolnej 2,73 $\pm 0,99(p=0,016)$ [9]. W badaniu, opublikowanym we wrześniu 2014 roku, Koenig i wsp. podjęli się próby porównania częstości występowania choroby wieńcowej, choroby naczyń mózgowych i naczyń obwodowych u 241 pacjentów z SLE i 193 osób z cukrzycą typu 1 (DM 1, diabetes mellitus type 1). Wyniki badania pokazały, że częstość powikłań naczyniowych u pacjentów z SLE jest co najmniej taka sama jak u pacjentów z DM 1. W grupie z SLE odnotowano 13,3\% zdarzeń naczyniowych: 8,3\% stanowiła choroba niedokrwienna serca, 
5\% - choroby naczyniowo-mózgowe, 1,2\% - zajęcie tętnic obwodowych. W grupie z DM 1 odnotowano 15\% zdarzeń naczyniowych: 9,3\% stanowiła choroba niedokrwienna serca, 3,1\% - choroby naczyniowo-mózgowe, 5,6\% - zajęcie tętnic obwodowych [10]. Patogeneza przyśpieszonej aterogenezy w grupie chorych z SLE nie jest do końca poznana. Wydaje się, że przyczyną tego stanu są złożone zaburzenia immunologiczne, między innymi aktywacja makrofagów, limfocytów T, nadmierne wytwarzanie poliklonalnych autoprzeciwciał (m.in. przeciwciał przeciwjądrowych, przeciwciał antykardiolipinowych [aCL, anticardiolipin antibodies], przeciwciał przeciwko białku C-reaktywnemu [CRP, $\mathrm{C}$ reactive protein] oraz przeciwciał przeciwko komórkom śródbłonka naczyniowego [AECA, antiendothelial cell antibodies]) oraz licznych cytokin (m.in. interleukiny 1 [IL-1], IL-6, IL-8, IL-12, IL-10, czynnika martwicy nowotworu [TNF, tumor necrosis factor], interferonu y [IFN-y]). Krążące kompleksy immunologiczne odkładają się w naczyniach, powodując dysfunkcję śródbłonka. Przewlekłe uszkodzenie naczyń zapoczątkowuje reakcję zapalną i prowadzi do przyśpieszonej aterogenezy niezależnie od tradycyjnych czynników ryzyka. Pęknięta blaszka miażdżycowa jest najczęstszą przyczyną ostrego zespołu wieńcowego. Warto jednak pamiętać, że u pacjentów z SLE może dojść do niedokrwienia mięśnia sercowego wtórnie do zakrzepicy, zatorowości lub procesu zapalnego w naczyniach bez istotnej miażdżycy w ocenie angiograficznej. Aktualnie trwają badania mające na celu walidację metod diagnostycznych umożliwiających wczesne wykrycie pacjentów zagrożonych chorobą wieńcową. Naukowcy skupiają swoją uwagę na nowych biomarkerach przyśpieszonej aterogenezy, do których zaliczane są między innymi: przeciwciała antyfosfolipidowe (aPL, antiphospholipid antibodies), białko C-reaktywne (CRP, C-reactive protein)/białko C-reaktywne o wysokiej czułości (hs-CRP, high-sensitivity C-reactive protein), paroksonaza 1 (PON1), adiponektyna, anneksyna $A 5$, asymetryczna dimetyloarginina (ADMA, asymmetric dimethylarginine), C3 i C5a, E-selektyna, białko wiążące kwasy tłuszczowe 4 (FABP4, fatty acid-binding protein), cząsteczki adhezji międzykomórkowej (ICAM, intercellular adhesion molecule), aktywność IFN typu I, leptyna, utleniona lipoproteina o niskiej gęstości (ox-LDL, oxidized low-density lipoprotein)/utlenione fosfolipidy (ox-PAPC, oxidized 1-palmitoyl-2-arachidonyl-sn-glycero-3-phosphorylcholine), przeciwciała przeciw ox-LDL, prozapalna lipoproteina o wysokiej gęstości (piHDL, proinflammatory high-density lipoprotein), TNF $\alpha$, cząsteczki adhezji komórkowej naczyń (VCAM, vascular cell adhesion molekule), czynnik von Willebranda (vWf, von Willebrand factor), całkowita lepkość krwi, produkcja przez erytrocyty tlenku azotu (NO), obniżone stężenie witaminy D [11].

Ponadto w grupie chorych z SLE wykazano przydatność badań obrazowych oceniających funkcję śródbłonka, sztywność dużych tętnic oraz grubość kompleksu intima-media (IMT, intima-media thickness) [12]. Ocena względnej zmia- ny średnicy tętnicy w odpowiedzi na niedokrwienie (FMD\%, flow-mediated dilatation) jest uznaną metodą badania funkcji śródbłonka. Opublikowana niedawno przez Wang i wsp. metanaliza 22 badań dotyczących oceny FMD\% u pacjentów z SLE (obejmująca 1199 chorych z SLE oraz 781 badanych z grupy kontrolnej) wykazała znaczące obniżenie FMD\% (standaryzowana średnia różnica [SMD, standardized mean difference] -1,19; $95 \% \mathrm{Cl},-1,63$, $-0,74 ; p<0,001)$ w grupie osób z SLE, a także udowodniła istotną rolę FMD\% we wczesnym wykrywaniu dysfunkcji śródbłonka, która przyczynia się do rozwoju miażdżycy [13].

Mimo częstszego występowania miażdżycy u chorych z SLE w chwili obecnej nie zaleca się rutynowych badań przesiewowych u pacjentów bezobjawowych. Osoby z SLE powinni mieć świadomość zwiększonego ryzyka wystąpienia zdarzeń sercowo-naczyniowych. Należy zachęcać chorych do modyfikacji stylu życia i eliminacji pozostałych czynników obciążających, takich jak: nikotynizm, nadwaga czy siedzący tryb życia. Leczenie hipercholesterolemii i AH nie odbiega od klasycznych wytycznych dla populacji ogólnej. Preferowane są statyny z uwagi na ich plejotropowe działanie. Dużo kontrowersji budzi przewlekła terapia GKS. Jest to leczenie obciążone wyjątkowo niekorzystnym wpływem na układ krążenia, jednak w przypadku chorób autoimmunologicznych GKS niejednokrotnie są niezbędne, aby zapewnić prawidłowe funkcjonowanie życiowo ważnych narządów. Czas farmakoterapii i dawki GKS powinny być zredukowane tak, aby ograniczyć działania niepożądane tych leków. Wpływ terapii immunosupresyjnej na układ sercowo-naczyniowy wciąż wymaga rzetelnej analizy. W badaniach retrospektywnych pacjenci z chorobą wieńcową częściej otrzymywali azatioprynę - nie ma jednak jednoznacznych danych potwierdzających aterogenny wpływ tego leku [11]. Istnieją doniesienia o potencjalnie kardioprotekcyjnym efekcie leków przeciwmalarycznych oraz mykofenolanu mofetylu [11].

\section{Zapalenie osierdzia}

Zapalenie osierdzia jest najczęstszym kardiologicznym powikłaniem SLE (> 50\% pacjentów), które ponadto koreluje z aktualną aktywnością choroby w innych narządach [14]. Rosenbaum i wsp. ocenili 71 pacjentów z SLE przyjętych do szpitala z rozpoznaniem zapalenia osierdzia. Wśród badanych chorych u $41(57,74 \%)$ potwierdzono obecność płynu w worku osierdziowym. Tamponadę serca stwierdzono u 9 (12,67\%) pacjentów (były to wyłącznie kobiety ze znamiennie obniżonym stężeniem składowej C4 dopełniacza) [15]. Zapalenie osierdzia może być również przyczyną nawracających, nietypowych dolegliwości bólowych w klatce piersiowej. Najczęściej jednak przebiega bezobjawowo i jest wykrywane przypadkowo jako pierwszy objaw rozwijającego się SLE. W diagnostyce kluczowe jest przeprowadzenie badania echokardiograficznego serca. Pomocne mogą być również badanie radiologiczne (RTG) klatki piersiowej 
(powiększona sylwetka serca) oraz badanie elektrokardiograficzne (EKG) (rozlane uniesienie odcinka ST i niski woltaż zespołów QRS). Do rzadkości należy masywny wysięk w worku osierdziowym prowadzący do tamponady serca oraz ropny wysięk u pacjentów leczonych immunosupresyjnie. Większość przypadków zapalenia osierdzia dobrze odpowiada na leczenie niesteroidowymi lekami przeciwzapalnymi (NSAID, non-steroidal anti-inflammatory drugs) lub małymi dawkami steroidów. W przypadku braku poprawy mimo leczenia należy rozważyć inne przyczyny zapalenia osierdzia (przede wszystkim: infekcję bakteryjną, gruźlice, proces nowotworowy).

\section{Zapalenie mięśnia sercowego}

Zapalenie mięśnia sercowego (myocarditis) występuje u 8-25\% pacjentów z SLE i przebiega zazwyczaj bezobjawowo $[16,17]$. Podejrzenie choroby sugeruje niewyjaśniona niewydolność serca, utrzymująca się arytmia oraz niespecyficzne zmiany odcinka ST i załamka T w elektrokardiogramie. W EKG niekiedy obserwuje się zarówno upośledzenie funkcji skurczowej, jak i rozkurczowej mięśnia lewej komory. Uogólniona hipokineza jako wykładnik zapalenia mięśnia sercowego występuje u około 6\% pacjentów z SLE. Rezonans magnetyczny serca (CMR, cardiovascular magnetic resonance) coraz częściej stanowi narzędzie wspomagające diagnozę zapalenia mięśnia sercowego. Opracowane przez ekspertów kryteria rozpoznawania zapalenia mięśnia sercowego w CMR pozwalają na ustalenie rozpoznania z dokładnością do 78\% [18]. Biopsja serca może być konieczna do różnicowania aktywnego procesu zapalnego, włóknienia i innych przyczyn kardiomiopatii. Warto wspomnieć, że niektóre leki stosowane w leczeniu SLE mogą powodować kardiomiopatię, na przykład cyklofosfamid i leki przeciwmalaryczne. Niestety, na chwilę obecną nie ma udowodnionych, skutecznych metod leczenia zapalenia mięśnia sercowego w przebiegu SLE. Terapia opiera się na kombinacji GKS z innymi lekami immunosupresyjnymi oraz klasycznym leczeniu niewydolności serca.

\section{Zajęcie wsierdzia i wady zastawkowe}

Proces chorobowy może dotyczyć zastawek serca i nie koreluje z aktualną aktywnością choroby, leczeniem lub czasem trwania SLE [19]. W pierwszej kolejności zajmowany jest aparat zastawkowy lewej części serca - najczęściej zastawka mitralna. Niegroźne szmery nad sercem (16-44\% szmery skurczowe; 1-3\% szmery rozkurczowe) są częstym zjawiskiem osłuchowym u pacjentów z SLE z powodu współistnienia anemii, stanów gorączkowych, zapalenia mięśnia sercowego. Głośny szmer nad zastawką mitralną lub aortalną powinien budzić podejrzenie patognomoniczne dla SLE nieinfekcyjnego zapalenia wsierdzia typu Libmana i Sacksa. Podobnie jak zapalenie mięśnia sercowego, zapalenie wsierdzia w przebiegu SLE jest rzadko diagnozowane przyżyciowo (6-11\%, jeśli do diagnostyki używano echokardiografii przezklatkowej; 43\% przy użyciu echokardiografii przezprzełykowej) [20, 21]. Wegetacje (składające się z kompleksów immunologicznych, komórek jednojądrzastych, włóknika, fibryny) znajdują się zazwyczaj na brzegach płatków zastawki mitralnej, rzadziej aortalnej/ /trójdzielnej. W procesie włóknienia i wapnienia wegetacji dochodzi do deformacji zastawek. Nieinfekcyjne zapalenie wsierdzia pozostaje zazwyczaj bezobjawowe. Niekiedy wegetacje mogą ulec fragmentacji, powodując udar niedokrwienny mózgu lub zawał serca. Pacjenci z SLE z zajęciem zastawek serca częściej w porównaniu z pacjentami bez chorób zastawkowych doznają udaru mózgu, incydentów zatorowych, niewydolności serca oraz infekcyjnego zapalenia wsierdzia [20].

Roldan i wsp. ocenili morfologię i funkcję zastawek u 69 pacjentów z SLE za pomocą echokardiografii przezprzełykowej. Nieprawidłowości w badaniu wykazano u 58 osób (84\%). Najczęściej stwierdzano: pogrubienie płatków (51-52\%), wegetacje bakteryjne/niebakteryjne (43\%), niedomykalność (28\%) lub stenozę (3-4\%) zastawki mitralnej i/lub aortalnej. W ponad 4-letniej obserwacji złożony punkt końcowy w postaci udaru mózgu, zatorowości obwodowej, niewydolności serca, zapalenia wsierdzia, konieczności wymiany aparatu zastawkowego wystąpił u 22\% pacjentów ze stwierdzanymi wyjściowo nieprawidłowościami zastawkowymi i u 8\% osób z prawidłowymi zastawkami [20].

Posiewy krwi i kontrolne badanie echokardiograficzne serca powinny być przeprowadzone w przypadku gorączki z towarzyszącym nowym szmerem nad sercem. Profilaktyczna antybiotykoterapia przed zabiegami dentystycznymi nie jest obecnie zalecana. Niemniej jednak warto rozważyć takie postępowanie u pacjentów leczonych immunosupresyjnie, ze znamiennym uszkodzeniem zastawek, przed planowanym zabiegiem powodującym przejściową bakteriemię. W szeregu badań wykazano częstsze występowanie zmian zastawkowych u pacjentów z obecnością aPL. W trzech europejskich ośrodkach uniwersyteckich przeprowadzono badania echokardiograficzne u łącznie 132 pacjentów z SLE. Nieprawidłowości zastawkowe stwierdzono u 22\% chorych z SLE oraz u 2,9\% badanych z grupy 68 zdrowych ochotników. Ponadto u 50 osób z SLE (38\%) stwierdzono obecność aPL. W grupie tej wegetacje (16\%) oraz niedomykalność mitralną (38\%) obserwowano znacznie częściej niż u pacjentów z SLE nieposiadających aPL (odpowiednio wegetacje 1,2\% i niedomykalność mitralna 12\%) [22].

W innym badaniu poddano ocenie echokardiograficznej 61 pacjentów z SLE i powtórzono badanie po około 8 latach. W tym okresie liczba stwierdzanych nieprawidłowości aparatu zastawkowego wzrosła z 39\% do 73\%, z czego 7 pacjentów (12\%) rozwinęło ciężką wadę zastawkową. Duża niedomykalność mitralna częściej występowała u pacjentów z wysokim mianem aCL w klasie immunoglobuliny G $(\lg G)(p=0,001) . W$ trwającej średnio 14 lat obserwacji 
złożony punkt końcowy w postaci udaru mózgu, zatorowości obwodowej, konieczności wymiany aparatu zastawkowego i zgonu wystąpił u 86\% osób z ciężką niedomykalnością mitralną w porównaniu z 25\% osób bez stwierdzanej dużej wady zastawkowej $(p=0,001)$ [23]. Biorąc pod uwage dotychczasowe doniesienia, grupa chorych z obecnymi w aPL powinna podlegać systematycznej ocenie echokardiograficznej.

\section{Zaburzenia rytmu serca i przewodzenia}

Zaburzenia rytmu serca i przewodzenia występują u 34-70\% pacjentów z SLE [17]. Najczęściej obserwuje się przewlekłą spoczynkową tachykardię zatokową (ok. 50\%) związaną z aktualnym zaostrzeniem choroby, ograniczoną sprawnością fizyczną lub bezobjawowym procesem zapalnym osierdzia [24]. Ponadto w przebiegu SLE mogą występować dodatkowe przedwczesne pobudzenia przedsionkowe i blok przedsionkowo-komorowy I stopnia (najczęściej przejściowy). Komorowe zaburzenia rytmu serca, zaburzenia przewodzenia śródkomorowego oraz blok przedsionkowo-komorowy II-III stopnia należą do rzadkości. Badania autopsyjne wykazały, że główną rolę w patogenezie dysfunkcji układu bodźco-przewodzącego odgrywa przewlekły proces zapalny prowadzący do postępującego włóknienia mięśnia sercowego [25]. Wyniki oceny spoczynkowego i 24-godzinnego monitorowania zapisu EKG u 36 chorych z SLE, przeprowadzonego przez Wranicza i wsp. [26], potwierdziły występowanie istotnej tachykardii zatokowej wśród badanych chorych w porównaniu z 35 osób zdrowych. U chorych z SLE nierzadko obserwuje się też zaburzenia repolaryzacji. W badaniu przeprowadzonym przez Cardoso i wsp. porównano zapisy EKG 140 kobiet z SLE do 37 osób z grupy kontrolnej. Pacjentki z SLE miały istotnie wydłużony czas trwania skorygowanego odstępu QT (QTc, corrected QT interval) oraz zwiększoną dyspersję QT (QTd, QT dispersion) (QTc 427 ms v. 410,05 ms; p < 0,001; QTd 52,38 ms v. $37,12 \mathrm{~ms} ; \mathrm{p}<0,001$ ) [27].

Bourré-Tessier i wsp. [28] w grupie 278 pacjentów z SLE wykazali związek wydłużonego odstępu QTc z obecnością przeciwciał anty-Ro (iloraz szans [OR, odds ratio] 5,1; 95\% Cl 1,5-17,4). U pacjentów, u których stwierdzono obecność przeciwciał anty-Ro istnieje zwiększone prawdopodobieństwo wydłużenia odstępu QTc i wystąpienia groźnego dla życia częstoskurczu komorowego typu torsade de pointes. Warto wspomnieć, że u płodów i noworodków matek z SLE, u których wykryto przeciwciała anty-Ro lub anty-La może dojść do całkowitego bloku przedsionkowo-komorowego (1-3\%) [29]. Z tego powodu celowe jest oznaczenie ciężarnym pacjentkom z SLE stężenia przeciwciał anty-Ro i anty-La na początku ciąży.

\section{Nadciśnienie tętnicze}

Nadciśnienie tętnicze rozwija się u około 70\% pacjentów z SLE [30]. Najczęściej jest konsekwencją przewlekłej cho- roby nerek wynikającej z nefropatii toczniowej. Drugim istotnym czynnikiem AH jest przewlekła kortykosteroidoterapia.

Petri i wsp. [31] badali wpływ zwiększenia dawki prednizonu u pacjentów z SLE (264 osoby oceniane podczas 3027 wizyt). Okazało się, że zmiana dawki o 10 mg związana jest ze zwiększeniem stężenia cholesterolu całkowitego w surowicy krwi o 7,5 $\pm 1,46 \mathrm{mg} / \mathrm{dl}$ oraz zwiększeniem ciśnienia tętniczego krwi o 1,1 mm Hg [31].

Wszyscy chorzy powinni regularne kontrolować ciśnienie tętnicze w warunkach ambulatoryjnych. Wczesne rozpoznanie i odpowiednie leczenie AH zapobiega przerostowi mięśnia lewej komory i wtórnej niewydolności serca. U pacjentów z rozpoznanym AH, jeśli jest to tylko możliwe, zaleca się zmniejszenie dawek GKS. W farmakoterapii $\mathrm{AH}$ preferowane są inhibitory konwertazy angiotensyny u pacjentów z nefropatią toczniową oraz antagoniści wapnia u pacjentów z objawem Raynauda. Rekomendowane jest intensywne leczenie hipotensyjne, podobnie jak dla pacjentów z DM lub przewlekłą chorobą nerek [10].

\section{Powikłania zakrzepowo-zatorowe}

w przebiegu zespołu antyfosfolipidowego Pacjenci z SLE oraz obecnością aPL mogą rozwinąć zagrażający życiu zespół antyfosfolipidowy (APS, antiphospholipid syndrome). Przeciwciała antyfosfolipidowe są heterogenną grupą przeciwciał skierowanych przeciwko białkom osocza (m.in. $\beta_{2}$-glikoproteinie I [ $\beta_{2} \mathrm{GPI}$ ], protrombinie, aneksynie $\mathrm{V}$, białku C, białku S, czynnikowi XII, trombinie) - wykazującym powinowactwo do fosfolipidów błony komórkowej (kardiolipiny, fosfatydyloseryny, fosfatydyloinozytolu, kwasu fosfatydowego, fosfatydylocholiny, fosfatydyloetanoloaminy) [1]. Do aPL zaliczane są aCL, przeciwciała przeciw $\beta_{2} \mathrm{GPI}$ oraz antykoagulant toczniowy (LA, lapus anticoagulant). Patogenezę zespołu przypisuje się prozakrzepowemu działaniu aPL, na które składają się:

- aktywacja komórek śródbłonka naczyń;

- zaburzenia funkcji naturalnego antykoagulanta $\beta_{2} \mathrm{GPI}$;

- zwiększenie aktywności protrombiny w przypadku upośledzenia właściwości antykoagulacyjnych białka C i aneksyny $\mathrm{V}$;

- hamowanie układu fibrynolitycznego;

- zwiększone powstawanie mikrocząstek pochodzenia płytkowego i śródbłonkowego aktywujących proces krzepnięcia.

Klinicznie APS objawia się zakrzepicą żylną lub tętniczą oraz niepowodzeniami położniczymi (nawracające poronienia, poród przedwczesny, obumarcie płodu, stan przedrzucawkowy, niewydolność łożyska, ograniczony wzrost płodu). Najczęstszą postacią APS jest zakrzepica żył głębokich kończyn dolnych (często występująca obustronnie i nawracająca). W prospektywnym, kohortowym badaniu przeprowadzonym w Finlandii w latach 1971-2009 oceniającym 119 pacjentów (89\% kobiet) z dodatnimi aPL (większość grupy badanej stanowili pacjenci z SLE) wykazano, że 
osoby, u których stwierdzono obecność przynajmniej dwóch przeciwciał z grupy aPL cechuje 2-krotnie wyższe ryzyko wystąpienia zdarzeń zakrzepowych w porównaniu ze zdrową populacją rasy kaukaskiej [32]. W innym wieloośrodkowym badaniu w ciągu 10 lat obserwowano 1000 pacjentów z APS (36,2\% APS wtórny do SLE) epizod zakrzepowo-zatorowy (w postaci udaru, zakrzepicy żył głębokich, przejściowego napadu niedokrwienia mózgu, zatorowości płucnej) wystąpił u $166(16,6 \%)$ pacjentów w ciągu pierwszych 5 lat i u $115(14,4 \%)$ pacjentów w ciągu kolejnych 5 lat. Odnotowano 93 zgony (9,3\%), których główną przyczyną była ciężka zakrzepica [33].

U 14-20\% pacjentów z APS wtórnym do SLE występuje zatorowość płucna [1]. Nawracające epizody zatorowości moga prowadzić do przewlekłego zakrzepowo-zatorowego nadciśnienia płucnego (PH, pulmonary hypertension). Zdarza się, że zakrzepica lub zator naczyń wieńcowych powoduje dławicę lub zawał serca. U pacjentów z APS dochodzi również do niewielkich zmian zakrzepowych na powierzchni wsierdzia, co objawia się pogrubieniem płatków zastawek (głównie mitralnej, rzadziej aortalnej). Drobne nieinfekcyjne wegetacje prowadzą do upośledzenia funkcji zastawek, a także stanowią czynnik ryzyka incydentów naczyniowo-mózgowych. U około 20\% pacjentów z APS występują objawy niedokrwienia ośrodkowego układu nerwowego w postaci udaru niedokrwiennego lub przemijającego napadu niedokrwienia mózgu (TIA, transient ischemic attack) [1]. Wskutek powtarzających się bezobjawowych mikroudarów może rozwinąc się otępienie. Janardhan i wsp. [34], badając grupę 2712 kobiet (średnia wieku 59,3 roku) i 2262 mężczyzn (średnia wieku 58,3 roku), wykazali, że podwyższone stężenie aCL, niezależnie od innych czynników ryzyka incydentów naczyniowo-mózgowych, istotnie zwiększa ryzyko udaru lub TIA u kobiet (współczynnik ryzyka [HR, hazard ratio] 2,6; 95\% Cl 1,3-5,4), lecz nie u mężczyzn (HR 1,3; 95\% Cl 0,7-2,4). Ponadto zakrzepica związana z APS może objąć łożysko naczyniowe dowolnego narządu. Zmiany zakrzepowo-zatorowe niekiedy dotyczą tętnicy/żyły środkowej siatkówki (powodując przemijającą nagłą jednooczną ślepotę; amaurosis fugax), naczyń nerkowych (prowadząc do zawału nerki, wewnątrznerkowej mikroangiopatii zakrzepowej, nadciśnienia i przewlekłej choroby nerek), naczyń trzewnych (zawał śledziony, trzustki lub nadnerczy), łożyska wątrobowego (będących przyczyną zespołu Budda-Chiariego).

Rzadką sytuacją kliniczną jest katastrofalny APS objawiający się ostrą niewydolnością wielonarządową (śmiertelność sięga 50\%). Do czynników wywołujących katastrofalny APS zaliczane są: zakażenia z następowym zespołem ogólnoustrojowej reakcji zapalnej, zabiegi chirurgiczne, nieskuteczne leczenie przeciwkrzepliwe, uraz, stres. U bezobjawowych pacjentów z SLE i obecnością aPL należy rozważyć profilaktyczne stosowanie kwasu acetylosalicylowego. W sytuacjach zwiększonego ryzyka zakrzepicy (np. unieruchomienie, połóg) należy stosować heparynę drobnocząsteczkową w dawkach profilaktycznych. Po epizodzie zakrzepicy żylnej sugerowane jest przewlekłe leczenie doustnym lekiem przeciwkrzepliwym i ewentualne dołączenie kwasu acetylosalicylowego w przypadku zakrzepicy tętniczej. W optymalizacji leczenia należy brać pod uwagę indywidualne ryzyko zakrzepicy, wynikające między innymi z profilu aPL, obecności dodatkowych czynników ryzyka sercowo-naczyniowego, pierwszego/kolejnego epizodu zakrzepicy oraz ryzyka krwawienia.

\section{Nadciśnienie płucne}

Według aktualnych wytycznych Europejskiego Towarzystwa Kardiologicznego (ESC , European Society of Cardiology) $\mathrm{PH}$ rozpoznaje się, gdy średnie spoczynkowe ciśnienie w tętnicy płucnej zmierzone podczas cewnikowania serca wynosi przynajmniej $25 \mathrm{~mm} \mathrm{Hg} \mathrm{[35].} \mathrm{U} \mathrm{pacjentów} \mathrm{z} \mathrm{SLE}$ najczęściej jest to tętnicze nadciśnienie płucne (PAH, pulmonary arterial hypertension) (grupa 1), nadciśnienie płucne wtórne do uszkodzenia płuc (grupa 3) lub przewlekłe zakrzepowo-zatorowe nadciśnienie płucne (CTEPH, chronic thromboembolic pulmonary hypertension) (grupa 4). U podłoża PAH w przebiegu SLE leży wiele mechanizmów, między innymi:

- skurcz naczyń płucnych (dysfunkcyjny śródbłonek produkuje mniej substancji naczyniorozszerzających - NO i prostacykliny);

- przebudowa naczyń płucnych z proliferacją i zwężeniem ich światła (nadmierna ekspresja związków naczynioskurczowych - tromboksanu $A_{2}$ i endoteliny 1 -zwiększa napięcie naczyniowe i sprzyja proliferacji komórek śródbłonka, mięśni gładkich, fibroblastów, a także wytwarzanie kolagenu, elastyny, fibronektyny w macierzy zewnątrzkomórkowej);

- mechanizmy immunologiczne związane z przewlekłym zapaleniem (w naczyniach płucnych stwierdzane są złogi przeciwciał przeciwjądrowych, antykoagulanta tocznia, czynnika reumatoidalnego IgG o zwiększonym mianie i dopełniacza).

Ponadto u osób z SLE może wystąpić włóknienie śródmiąższowe płuc, będące przyczyną $\mathrm{PH}$ wtórnego do chorób płuc, a także epizody zakrzepowo-zatorowe, które przyczyniają się do powstawania CTEPH. Wszystkie wymienione procesy prowadzą do zwiększenia oporu płucnego, a w konsekwencji do przeciążenia jam prawego serca i prawokomorowej niewydolności serca. W schyłkowej fazie choroby może występować zespół małego rzutu i zgon. Nadciśnienie płucne rozwija się u 4-14\% pacjentów z SLE [36]. Li i wsp. wykazali PH u 18 (4,3\%) z 419 chorych z SLE. W toku dalszej obserwacji trwającej średnio 23,6 miesiąca 4 (22\%) osoby z tej grupy zmarły [37]. Objawy PH pojawiają się w zaawansowanym stadium choroby, a pierwsze objawy są niecharakterystyczne. Chorzy zgłaszają osłabienie, męczliwość, pogorszenie tolerancji wysiłku, kołatanie serca, 
zasłabnięcia, duszność wysiłkową, a następnie spoczynkową. U pacjentów z SLE i podejrzeniem PH zaleca się przesiewowe badanie echokardiograficzne (klasa zaleceń I C) [35]. U osób z istotnym podejrzeniem $\mathrm{PH}$ w badaniu echokardiograficznym rekomendowane jest przeprowadzenie cewnikowania prawego serca. Od chwili ustalenia rozpoznania $\mathrm{PH}$ w ciągu 2 lat całkowita śmiertelność w tej grupie chorych wynosi 25-50\% [38]. Pacjenci z SLE powinni być monitorowani w celu wczesnego wykrycia i wdrożenia odpowiedniego leczenia $\mathrm{PH}$, co w wielu przypadkach ma kluczowe znaczenie dla rokowania i komfortu życia.

\section{Wnioski}

Większość pacjentów z SLE rozwinie powikłania sercowo-naczyniowe wtórnie do choroby podstawowej lub do zastosowanego leczenia (GKS). Jednym z najgroźniejszych powikłań SLE jest przedwczesna miażdżyca tętnic wieńcowych, występująca często u młodych kobiet. Zdarzenia sercowo-naczyniowe stanowią główną przyczynę zgonów w tej grupie chorych. Obserwacje wskazują na negatywny wpływ przewlekłej steroidoterapii. Istnieją też dowody, że krążące kompleksy immunologiczne, aktywność składowych dopełniacza i w konsekwencji reakcja zapalna odpowiedzialne są za rozwój choroby serca i naczyń u pacjentów z SLE, jednak pełna patogeneza pozostaje wciąż nieznana. Naukowcy podkreślają potrzebę prowadzenia dalszych badań w celu pełnego wyjaśnienia złożonych zaburzeń immunologicznych w tej chorobie. W przebiegu
SLE obserwuje się także zapalenie osierdzia - poddające się leczeniu NSAID lub małymi dawkami GKS. Równie często występuje AH i nieme klinicznie zapalenie mięśnia sercowego. Nieinfekcyjne zapalenie wsierdzia typu Libmana i Sacksa powinno być brane pod uwagę u wszystkich chorych z aPL oraz z istotnym uszkodzeniem zastawek (najczęściej niedomykalnością mitralną i stenozą aortalną). Kluczowe w diagnostyce różnicowej w takich sytuacjach jest wykluczenie infekcyjnego zapalenia wsierdzia. Pacjenci z obecnością aPL mogą rozwinąć powikłania zakrzepowo-zatorowe w przebiegu APS - u tych chorych również należy rozważyć przewlekłe leczenie przeciwkrzepliwe. Leczenie przeciwkrzepliwe jest zalecane u wszystkich chorych po epizodzie zatorowym, niezależnie od obecności aPL. Jednym z najgorzej rokujących, ale stosunkowo rzadkich powikłań naczyniowych jest PH. Rozwija się ono powoli, może jednak prowadzić do prawokomorowej niewydolności serca, zespołu małego rzutu i zgonu. Ponadto chorzy z SLE mogą prezentować spoczynkową tachykardię zatokową oraz przejściowy blok przedsionkowo komorowy I stopnia (rzadko występują inne groźne zaburzenia rytmu i przewodzenia). Ciężarne kobiety z przeciwciałami anty-Ro lub anty-La powinny być szczególnie uważnie monitorowane z uwagi na zwiększone ryzyko wystąpienia całkowitego bloku serca u płodu/noworodka.

\section{Konflikt interesów}

Autorzy deklarują brak konfliktu interesów.

\section{Abstract}

Systemic lupus erythematosus (SLE) is a systemic chronic, inflammatory, autoimmune disease, characterized by various clinical manifestations and production of multiple autoantibodies. Complex immune system dysfunctions as well as chronic inflammatory processes lead to internal organs and tissue failure. The most common cardiovascular manifestations among patients with SLE include accelerated coronary heart disease (CHD), pericarditis, myocarditis, valvular disease, Libman-Sacks nonbacterial endocarditis - the most characteristic cardiac manifestation of the SLE, conduction abnormalities, pulmonary hypertension (PH), thromboembolic events, arterial hypertension (AH) and heart failure. Accelerated atherosclerosis with CHD is of key importance for prognosis, particularly among young women. An increased risk of cardiovascular events among patients with SLE has been confirmed in multiple studies. Getting closer to understanding multiple mechanisms of cardiovascular disease and pathogenesis of atherosclerosis in SLE is critical to lower mortality rate in this group population. The aim of this article is to present aetiology and cardiovascular manifestations of processes of SLE.

Key words: systemic lupus erythematosus, cardiovascular manifestations, atherosclerosis, coronary heart disease

Folia Cardiologica 2016; 11, 2: 111-118 


\section{Piśmiennictwo}

1. Filipowicz-Sosnowska A., Zimmermann-Górska I., Musiał J. i wsp. Choroby układowe tkanki łącznej. W: Szczeklik A. (red.). Choroby Wewnętrzne. Stan wiedzy na rok 2011. Medycyna Praktyczna, Kraków 2011: 1743-1756.

2. Olesińska M. Toczeń rumieniowaty układowy. W: Puszczewicz M. (red.). Wielka interna - reumatologia. Medical Tribune Polska, Warszawa 2011: 97-113.

3. Schoenfeld S.R., Kasturi S., Costenbader K.H. The epidemiology of atherosclerotic cardiovascular disease among patients with SLE: a systematic review. Semin. Arthritis Rheum. 2013; 43: 77-95.

4. Bernatsky S., Boivin J.F., Joseph L. i wsp. Mortality in systemic lupus erythematosus. Arthritis Rheum. 2006; 54: 2550-2557.

5. Ballocca F., D'Ascenzo F., Moretti C. i wsp. Predictors of cardiovascular events in patients with systemic lupuserythematosus (SLE): a systematic review and meta-analysis. Eur. J. Prev. Cardiol. 2015; 22: 1435-1441.

6. Bulkley B.H., Roberts W.C. The heart in systemic lupus erythematosus and the changes induced in it by corticosteroid therapy. A study of 36 necropsy patients. Am. J. Med. 1975; 58: 243-264.

7. Haider Y.S., Roberts W.C. Coronary arterial disease in systemic lupus erythematosus; quantification of degrees of narrowing in 22 necropsy patients (21 women) aged 16 to 37 years. Am. J. Med. 1981; 70: 775-781.

8. Manzi S., Meilahn E.N., Rairie J.E. i wsp. Age-specific incidence rates of myocardial infarction and angina in women with systemic lupus erythematosus: comparison with the Framingham Study. Am. J. Epidemiol. 1997; 145: 408-415.

9. Rahman P., Urowitz M.B., Gladman D.D., Bruce I.N., Genest J. Jr. Contribution of traditional risk factors to coronary artery disease in patients with systemic lupus erythematosus. J. Rheumatol. 1999; 26: 2363-2368.

10. Koenig K.F., Ribi C., Radosavac M., Zulewski H., Trendelenburg M., Swiss SLE cohort study (SSCS). Prevalence of vascular disease in systemic lupus erythematosus compared with type-1 diabetes mellitus: a cross-sectional study of two cohorts. Lupus 2015; 24: 58-65.

11. McMahon M., Skaggs B. Pathogenesis and treatment of atherosclerosis in lupus. Rheum. Dis. Clin. North Am. 2014; 40: 475-495.

12. Fischer K., Brzosko M. Diagnosis of early atherosclerotic lesions, and selected atherosclerotic risk factors, in patients with systemic lupus erythematosus. Pol. Arch. Med. Wewn. 2009; 119: 736-742.

13. Wang D.G., Tang X.W., Fan Y. i wsp. Decreased flow-mediated dilatation in patients with systemic lupus erythematosus: a meta-analysis. Inflammation 2014; 37: 2067-2075.

14. Man B.L., Mok C.C. Serositis related to systemic lupus erythematosus: prevalence and outcome. Lupus 2005; 14: 822-826.

15. Rosenbaum E., Krebs E., Cohen M., Tiliakos A., Derk C.T. The spectrum of clinical manifestations, outcome and treatment of pericardial tamponade in patients with systemic lupus erythematosus: a retrospective study and literature review. Lupus 2009; 18: 608-612.

16. Moder K.G., Miller T.D., Tazelaar H.D. Cardiac involvement in systemic lupus erythematosus. Mayo Clin. Proc. 1999; 74: 275-284.

17. Mandell B.F. Cardiovascular involvement in systemic lupus erythematosus. Semin. Arthritis Rheum. 1987; 17: 126-141.

18. Petryka J., Miśko J., Małek Ł.A. i wsp. Zastosowanie rezonansu magnetycznego w diagnostyce zapalenia mięśnia sercowego. Kardiol. Pol. 2010; 68: 824-829.

19. Ong M.L., Veerapen K., Chambers J.B., Lim M.N., Manivasagar M., Wang F. Cardiac abnormalities in systemic lupus erythematosus: prevalence and relationship to disease activity. Int. J. Cardiol. 1992; 34: $69-74$.
20. Roldan C.A., Shively B.K., Crawford M.H. An echocardiographic study of valvular heart disease associated with systemic lupus erythematosus. N. Engl. J. Med. 1996; 335: 1424-1430.

21. Roldan C.A., Qualls C.R., Sopko K.S., Sibbitt W.L. Jr. Transthoracic versus transesophageal echocardiography for detection of Libman-Sacks endocarditis: a randomized controlled study. J. Rheumatol. 2008; 35: 224-229.

22. Khamashta M.A., Cervera R., Asherson R.A. i wsp. Association of antibodies against phospholipids with heart valve disease in systemic lupus erythematosus. Lancet 1990; 335: 1541-1544.

23. Perez-Villa F., Font J., Azqueta M. i wsp. Severe valvular regurgitation and antiphospholipid antibodies in systemic lupus erythematosus: a prospective, long-term, followup study. Arthritis Rheum. 2005; 53: 460-467.

24. Utset T.O., Ward A.B., Thompson T.L., Green S.L. Significance of chronic tachycardia in systemic lupus erythematosus. Arthritis Care Res. (Hoboken) 2013; 65: 827-831.

25. James T.N., Rupe C.E., Monteau R.W. Pathology of the conduction system in systemic lupus erythematosus. Ann. Intern. Med. 1965; 63: 402-410.

26. Wranicz J.K., Cygankiewicz I., Zielińska M., Woźniacka A., Sysa-Jedrzejowska A. Non-invasive cardiac evaluation in patients with systemic lupus erythematosus. J. Med. 2001; 32: 195-206.

27. Cardoso C.R., Sales M.A., Papi J.A., Salles G.F. QT-interval parameters are increased in systemic lupus erythematosus patients. Lupus 2005; 14: 846-852.

28. Bourré-Tessier J., Clarke A.E., Huynh T. i wsp. Prolonged corrected QT interval in anti-Ro/SSA-positive adults with systemic lupus erythematosus. Arthritis Care Res. (Hoboken) 2011; 63: 1031-1037.

29. Johansen A.S., Herlin T. Neonatal lupus syndrome. Association with complete congenital atrioventricular block. Ugeskr. Laeger. 1998; 160: 2521-2525.

30. Ryan M.J. The pathophysiology of hypertension in systemic lupus erythematosus. Am. J. Physiol. Regul. Integr. Comp. Physiol. 2009; 296: R1258-1267.

31. Petri M., Lakatta C., Magder L.,Goldman D. Effect of prednisone and hydroxychloroquine on coronary artery disease risk factors in systemic lupus erythematosus: a longitudinal data analysis. Am. J. Med. 1994; 96: 254-259.

32. Mustonen P., Lehtonen K.V., Javela K, Puurunen M. Persistent antiphospholipid antibody (aPL) in asymptomatic carriers as a risk factor for future thrombotic events: a nationwide prospective study. Lupus 2014; 23: 1468-1476.

33. Cervera R., Serrano R., Pons-Estel G.J. i wsp. Morbidity and mortality in the antiphospholipid syndrome during a 10-year period: a multicentre prospective study of 1000 patients. Ann. Rheum. Dis. 2015; 74: 1011-1018.

34. Janardhan V., Wolf P.A., Kase C.S. i wsp. Anticardiolipin antibodies and risk of ischemic stroke and transient ischemic attack: the Framingham cohort and offspring study. Stroke 2004; 35: 736-741.

35. Galiè N., Hoeper M.M., Humbert M. i wsp. Guidelines for the diagnosis and treatment of pulmonary hypertension: the Task Force for the Diagnosis and Treatment of Pulmonary Hypertension of the European Society of Cardiology (ESC) and the European Respiratory Society (ERS), endorsed by the International Society of Heart and Lung Transplantation (ISHLT). Eur. Heart J. 2009; 30: 2493-2537.

36. Ciurzyński M., Bienias P., Pruszczyk P. Nadciśnienie płucne u pacjentów z chorobami tkanki łącznej. Kardiol. Pol. 2007; 65: 994-1000.

37. Li E.K., Tam L.S. Pulmonary hypertension in systemic lupus erythematosus: clinical association and survival in 18 patients. J. Rheumatol. 1999; 26: 1923-1929.

38. Fagan K.A., Badesch D.B. Pulmonary hypertension associated with connective tissue disease. W: Peacock A.J., Rubin L.J. (red.). Pulmonary circulation. Arnold, London 2004; 181-190. 